\title{
Significance of fisheries discards for a threatened Mediterranean seabird, the Balearic shearwater Puffinus mauretanicus
}

\author{
José Manuel Arcos ${ }^{1,2, *}$, Daniel Oro \\ ${ }^{1}$ Departament de Biologia Animal (Vertebrats), Universitat de Barcelona, Avda. Diagonal 645, 08028 Barcelona, Spain \\ ${ }^{2}$ Institut Mediterrani d'Estudis Avançats IMEDEA (CSIC-UIB), C/Miquel Marquès 21, 07190 Esporles, Mallorca, Spain
}

\begin{abstract}
The Balearic shearwater Puffinus mauretanicus is the rarest and most threatened Mediterranean seabird. The biology of this shearwater is poorly understood, and its study is important to design conservation strategies. We studied the feeding ecology of the Balearic shearwater at sea in the western Mediterranean (1996 to 2000), focusing on the importance of fisheries discards for this species. Fieldwork was conducted on board commercial bottom trawlers (demersal fishery with diurnal activity) and purse seiners (pelagic fishery with nocturnal activity), as well as during experimental trawling surveys. The shearwaters made extensive use of discards, mostly those from trawlers. This was especially so during the late breeding season, which could be related to the general impoverishment of Mediterranean surface waters. At this time of year, most birds foraged along the eastern Iberian coast, with the largest concentrations occurring off the Ebro Delta. This distribution seems determined by favourable local hydrographic conditions and by the presence of important trawling fleets. Balearic shearwaters captured discards by diving at some distance behind fishing vessels, thus reducing interactions with other seabirds. A bioenergetic model estimated that $40.8 \%$ of the energy obtained by the Balearic shearwater population comes from trawler discards during the breeding season (March to June), although this value was subject to strong variability $( \pm 36.2 \% \mathrm{SD})$. In addition to the capture of discards (38\% of the feeding instances observed), Balearic shearwaters also obtained food by capturing fish under floating drifting objects (33\%), associating with sub-surface predators (10\%), capturing small shoaling fish (10\%), and feeding upon plankton $(10 \%)$. The latter behaviour was observed in crepuscular hours, but the shearwaters did not appear to feed at night. In winter, Balearic shearwaters attended fishing vessels to a lesser extent. Upcoming fishing policies could affect Balearic shearwaters in the short term through reduction of discards, although good design of management strategies (such as trawling moratoria) could help to reduce their negative effects.
\end{abstract}

KEY WORDS: Conservation · Foraging · Purse seiners · Procellariforms · Seabird-fisheries interactions $\cdot$ Trawlers $\cdot$ Feeding ecology

\section{INTRODUCTION}

The Mediterranean basin contains a breeding seabird community characterised by a high level of endemism, thus being of special conservation concern (Zotier et al. 1999). The Balearic shearwater Puffinus

*E-mail: jmarcos@porthos.bio.ub.es mauretanicus is the rarest and most threatened Mediterranean seabird, with an estimated breeding population of 3300 pairs (Aguilar 1991) restricted to the Balearic Archipelago (western Mediterranean). The taxonomy of this shearwater has received considerable attention over the last century, first being considered as a subspecies of the Manx shearwater Puffinus puffinus (Lowe 1921), and later of the yelkouan shearwater Puffinus yelkouan (sharing specific identity with the

(C) Inter-Research $2002 \cdot$ www.int-res.com 
nominate form, the levantine shearwater; Bourne et al. 1988). Only recently has this shearwater been widely accepted as a distinct species, in the light of increasing palaeontological and molecular evidence, combined with the reconsideration of several morphological, ecological, and behavioural traits (see review in Mayol et al. 2000). Most of the research efforts conducted on the species have focused on this uncertain taxonomy, while its general ecology has been studied little. As a distinct species, the lack of general knowledge about this threatened shearwater is especially alarming, since a good understanding of its biology is important to design appropriate conservation strategies.

Particularly little is known about the feeding ecology of the Balearic shearwater, and is partly confounded by extrapolations made from its better-studied closest relatives, the Manx and the levantine shearwaters (cf. Le Mao \& Yésou 1993), which mostly forage in flocks upon small shoaling fish (e.g. Brooke 1990). This behaviour seems also common for the Balearic shearwater (Araujo et al. 1977, Rebassa et al. 1998), but not exclusive, with Balearic shearwaters having been reported capturing discards behind fishing vessels (Le Mao \& Yésou 1993, Oro \& Ruiz 1997), feeding in association with sub-surface predators (Oro 1995), capturing fish under floating drifting objects (Arcos et al. 2000), and feeding upon planktonic organisms on the sea surface (Le Mao \& Yésou 1993). Although these alternative feeding strategies have been often disregarded or considered of little importance (e.g. Snow \& Perrins 1998), they could play an important role in the feeding ecology of the Balearic shearwater, at least in some periods of the year. Special interest should be focused on the case of fisheries discards, an anthropogenic food resource that has strongly influenced the ecology of several gulls and terns in the NW Mediterranean (see Oro 1999 and references therein), although it is considered of rather little importance for the shearwaters (e.g. Mayol et al. 2000).

This study was directed to assess the significance of fisheries discards for the Balearic shearwater, as well as to ascertain what other feeding strategies might be important for this species. Seasonal and geographic variations in the use of discards were examined off the Mediterranean side of the Iberian Peninsula and the southernmost Balearic Islands, through cruises on board commercial fishing vessels (bottom trawlers and purse seiners) and experimental trawling surveys. We also recorded the behaviour of the shearwaters when attending fishing vessels, as well as their efficiency at capturing discards. A simple bioenergetic model allowed us to estimate the extent to which Balearic shearwaters make use of trawler discards during the breeding season, when the resource seemed most important for this species. Other feeding strategies were also recorded and quantified during this season. Detailed information on the use of fisheries discards by Balearic shearwaters, as well as on the significance of alternative feeding strategies, could help to predict the effect of incoming changes in fishing practices on this threatened seabird.

\section{MATERIALS AND METHODS}

Study area. The study area comprised the entire Mediterranean region off the Iberian Peninsula, as well as the southern isles of the Balearic Archipelago (Ibiza and Formentera; Fig. 1). We differentiated 4 areas according to their topographic and hydrographic features (see Estrada 1996, Salat 1996): (I) Alboran Sea-Vera Gulf; (II) Alicante-Ibiza; (III) Ebro DeltaColumbretes Islands; and (IV) central-north Catalonia. The Alboran Sea and the Vera Gulf are characterised by a narrow continental shelf, as well as by the direct influence of Atlantic surface waters, which lead to local areas of relatively high productivity. The continental shelf broadens in the Alicante-Ibiza area, where surface inflowing (modified) Atlantic and outflowing Mediterranean waters meet around the Ibiza sill. Around the Ebro Delta and the Columbretes Islands the continental shelf is widest (up to $70 \mathrm{~km}$ ), and the area is particularly productive as a combined effect of the Liguro-Provençal-Catalan slope front and the runoff of the Ebro River. In the central-north Catalonia area the continental shelf becomes narrow again, with the Liguro-Provençal-Catalan front flowing southwestwards along the continental slope.

Fisheries. Two commercial fishing practices were selected for study based on their importance in the western Mediterranean: bottom trawlers (diurnal activity) and purse seiners (nocturnal activity). The former target a wide variety of demersal species, generating large amounts of discards, while the latter target small pelagic fish, being more selective and usually generating few discards (Arcos 2001). In the Spanish Mediterranean the official census is ca. 1175 trawlers, whereas the number of purse seiners is lower and more difficult to determine with confidence (Lostado 1997). Since 1991, an increasing number of ports (though still not all) suspend trawling activities (moratoria) for 2 mo during the spring, coinciding with part of the breeding period of the Balearic shearwater (March to June; Mayol et al. 2000). Purse seiners are also subject to moratoria in some areas during the winter.

Cruises. Experimental trawling surveys were conducted on board the RV 'Cornide de Saavedra', during late spring of 1999 (4 May to 4 June) and 2000 (22 May to 22 June), covering the entire study area. In addition, 114 one-day cruises were performed on board commercial 
fishing vessels throughout the year in 2 specific zones: off the Ebro Delta (29 trawler cruises and 29 purse seine cruises, 1997 to 1998) and off Barcelona (58 trawler cruises, 1996 to 2000). The former area was selected due to its relatively high productivity (Estrada 1996), and because we expected that a substantial fraction of the breeding population of the Balearic shearwater would feed there (e.g. Abelló \& Oro 1998, Abelló et al. in press). The latter area was selected due to the large concentrations of Balearic shearwaters recorded there in winter (Gutiérrez \& Figuerola 1995). Data from commercial fishing vessels were considered separately for different seasons, defined according to the annual cycle of the Balearic shearwater: breeding period (March to June); post-breeding/moulting period (July to October); and pre-breeding/wintering period (November to February).

Censuses of birds attending fishing vessels. Seabirds attending fishing vessels were counted and identified to the species level at 15 min intervals during the fishing activity (from hauling the net through the whole discarding process). The largest of these counts was recorded per haul. In experimental trawling surveys, only 1 count was performed for each haul, shortly after hauling the net in.

To assess how the activity of trawlers influenced the numbers of attending shearwaters, each 15 min count was classified as: (1) net at the sea surface (while being either hauled or lowered); (2) normal discarding; (3) moments of low or no discards, before all the bycatch had been discarded (for more details, see Arcos et al. 2001). The mean number of shearwaters was then calculated for each activity and haul. At purse seiners, we differentiated between the hauling of the net (when seabirds capture fish concentrated near the sea surface, at night), and the discarding activity (usually of little importance, performed during the return to port at daylight; Arcos \& Oro 2002).

Discard experiments. Discard experiments aboard trawlers were conducted coinciding with the discarding activity at the vessel. Fish from the discard fraction were thrown overboard individually (about 5 to 10 fish $\mathrm{min}^{-1}$ ), after being identified to the species level and classified according to their length into 6 size classes (here regrouped into 3 classes: 0 to $9 \mathrm{~cm}, 10$ to $19 \mathrm{~cm}$, and $\geq 20 \mathrm{~cm}$ ). Each discarded item was followed until its final fate, either sunk or picked up by a seabird. In the latter case we recorded the seabird species, and whether the item was swallowed, lost, or kleptoparasitised by another bird. To minimise biases, we tried to throw items coinciding with larger amounts of fish thrown by fishermen (see further discussion in Arcos et al. 2001).

Counts of seabirds following the trawler were performed regularly during the discard experiments, and were recorded independently of the maximum number of seabirds recorded for the entire haul. These counts allowed calculation of a foraging success index for each experiment, based on Ivlev's electivity index (Krebs 1989), to assess the efficiency of the shearwaters at capturing discards relative to other species (cf. Arcos 2001, Arcos et al. 2001),

$$
S I=\frac{O-E}{O+E}
$$

Fig. 1. Map of the study area. The area where fieldwork was conducted is shown in grey. The 4 sectors considered were: Alboran Sea-Vera Gulf (I), Alicante-Ibiza (II), Ebro Delta-Columbretes (III), and central-north Catalonia (IV). Isobaths (200 and $1000 \mathrm{~m}$ ) are also shown where $S I$ is the foraging success index of Balearic shearwaters, $O$ is 
the observed number of items swallowed, and $E$ is the expected number of items swallowed, estimated from multiplying the total number of items offered by the representation (percentage) of the species behind the vessel. If this representation was observed to change substantially, the experiment was stopped. Only those experiments with more than 30 items discarded were considered, to minimise biases resulting from small sample size (Garthe \& Hüppop 1998a). The use of this index allows the comparison of relative efficiencies between species, and is easily interpreted as it is symmetrical (around zero) and finite (from -1 to +1 ).

We assessed fish size selection by Balearic shearwaters comparing the offer and the capture of fish of each size class. Similarly, we assessed fish-type selection, considering 7 main classes of fish species/groups (see Table 1). These groups were determined after examining sub-samples of discards during the breeding season of the Balearic shearwater, when the resource seems more important in its diet (see Results; $\mathrm{n}=11$ hauls, 2453 fish and $24.9 \mathrm{~kg}$ examined). A preference index $(P I)$ was calculated for each fish type group (i) as,

$$
P I_{i}=\frac{O_{i}}{E_{i}}
$$

where $O_{i}$ is the observed and $E_{i}$ the expected number of items swallowed by Balearic shearwaters. To avoid biases resulting from differences in the representation of each fish type group between experiments, $E_{i}$ was calculated separately for each experiment and resulting values were then summed as follows,

$$
E_{i}=\sum_{j=1}^{n}\left(C_{j} \times P_{i j}\right)
$$

where $C_{j}$ is the number of items captured by Balearic shearwaters at experiment $j(j=1,2, \ldots, \mathrm{n})$, and $P_{i j}$ is the proportion of items of fish type $i$ discarded in experiment $j$.

Strip-transect counts. During the experimental trawling surveys we performed strip-transect counts to estimate seabird densities (birds $\mathrm{km}^{-2}$ ), when the vessel was steaming between trawling stations. These counts were performed either $90^{\circ}$ or $180^{\circ}$ forward, depending on light conditions, considering a strip $300 \mathrm{~m}$ wide per side (thus prospecting a band of $600 \mathrm{~m}$ when counting at $180^{\circ}$ ) which was determined according to Heinemann (1981). Flying birds were counted using snapshots, following Tasker et al. (1984). Birds observed out of the strip were also recorded, although they were not included in the estimates of seabird densities. The units of census were 10 min counts. These units were often conducted in series or transects of longer duration (usually 2 to 4 counts transect ${ }^{-1}$, not exceeding 6 counts in $90 \%$ of cases), and data were gathered for each transect when general conditions (sea depth, distance to coast) did not change substantially. In total we conducted 972 counts, which were regrouped into 282 transects, covering an area of $1400 \mathrm{~km}^{2}$. Though results are presented as densities, they should be best regarded as relative measures for comparisons between different areas (cf. Haney 1985). For each transect we recorded the mean sea depth (categorised as 0 to 99, 100 to 199, and $\geq 200 \mathrm{~m}$ ), and the mean distance to the mainland coast ( 0 to 9,10 to 19 , and $\geq 20 \mathrm{n}$ mile). During transect counts, we recorded all instances of active feeding behaviour in Balearic shearwaters. In these occasions, we noted the feeding technique and the number of shearwaters involved. Birds associated with our vessel were always disregarded.

Bioenergetic model for Balearic shearwaters. As we could not determine directly the total amount of discards used by the shearwaters, and hence the significance of this food resource for the whole population of this seabird, we approached this point using a simple bioenergetic model. This model was restricted to the breeding season (March to June) and considered the whole population of Balearic shearwaters (adults plus immatures). We first calculated the percentage of trawler discards that the shearwaters eat and the energy content of the material ingested, after estimating the total amounts of discards available in a given area (see details below). We then determined the total energy requirements of the shearwater population during the breeding season. By dividing the energy obtained from the fishery discards $(E D)$ by the energetic requirements of the shearwaters $(E R)$, we estimated the proportion of energy demands met by the discards (discard significance, $D S$ ). In the calculation of $E D$ and $E R$, we considered several variables (see Table 2): amounts of commercial catches $(C C)$, ratio of

Table 1. Fish type species/groups selected according to their representation in discards. Values of the 3 variables used to estimate the average energy content of discards $(C A L)$ : preference index for each fish type group $\left(P I_{i}\right)$, representation in mass of each fish type group in discards $\left(M F_{i,} \%\right)$, and mean energy content of each fish type group $\left(C A L_{i}\right.$, in $\left.\mathrm{kJ} \mathrm{g}^{-1}\right)$

\begin{tabular}{|lccccc|}
\hline & $P I_{i}$ & \multicolumn{2}{c}{$M F_{;}$} & \multicolumn{2}{c|}{$C A L_{i}\left(\mathrm{~kJ} \mathrm{~g}^{-1}\right)$} \\
& & $(\%)$ & $M e a n$ & $\mathrm{SD}$ \\
\hline Sardine Sardina pilchardus & 1.45 & 18.61 & 10.03 & 0.97 \\
Anchovy Engraulis encrasicolus & 2.31 & 6.71 & 6.67 & 0.44 \\
Bogue Boops poops & 0.13 & 18.16 & 5.94 & 0.23 \\
Gadiformes & 1.39 & 21.43 & 5.81 & 0.75 \\
Gobiidae/Callionymidae & 1.50 & 14.59 & 5.34 & 0.47 \\
Pleuronectiformes & 0.64 & 7.67 & 5.28 & 0.42 \\
Others & 0.54 & 12.83 & 7.60 & 0.78 \\
\hline
\end{tabular}


fish discarded to commercial catch $(D R)$, consumable fraction of discards $(C F)$, discard fraction consumed by shearwaters $(C R)$, energy content $(C A L)$, assimilation efficiency $(A E)$, field metabolic rate $(F M R$, estimated from body mass $B M$ in $\mathrm{g}$ ), and number of shearwaters $\left(N_{\mathrm{S}}\right)$ :

$$
D S=\frac{E D}{E R}=\frac{C C \times D R \times C F \times C R \times C A L \times A E}{F M R \times N_{\mathrm{S}}}
$$

As most of these variables have some variability, a coefficient of variation (CV) of $D S$ was also estimated as a precision measure using the Delta method (Stratoudakis 1999):

$$
\begin{aligned}
& \mathrm{CV}^{2}(D S)= \\
& \mathrm{CV}^{2}(C C)+\mathrm{CV}^{2}(D R)+\mathrm{CV}^{2}(C F)+\mathrm{CV}^{2}(C R)+\mathrm{CV}^{2} \\
& (C A L)+\mathrm{CV}^{2}(A E)+\mathrm{CV}^{2}(F M R)+\mathrm{CV}^{2}(B M)+\mathrm{CV}^{2}\left(N_{\mathrm{S}}\right)
\end{aligned}
$$

Several inputs of the model had to be estimated from the literature on similar species or from data collected on few individuals, because many aspects of the feeding ecology (such as foraging ranges) and demography (such as immature survival rates or proportion of nonbreeders) are little known.

To estimate the energy obtained from discards $(E D)$ we first defined the area where most individuals may forage during the breeding season, according to our observations (see also Abelló et al. in press). This area comprises most of the Iberian Shelf (Barcelona to Santa Pola, see Fig. 2), and holds 576 trawlers. $C C$ at this area were estimated by multiplying the number of trawlers by the average amount of fish landed by each vessel, which in turn was estimated from data obtained at 4 ports (135 vessels) for the years 1994 to 1998 (March to June). This allowed the estimation of the amounts of discards available to seabirds, by applying $D R$ and the a priori $C F$ to the model. We then considered the percentage of (consumable) discards captured by Balearic shearwaters $(C R)$ to compute the total amount of discards consumed. $C R$ was estimated as a numeric percentage (\% of fish offered that were captured by shearwaters), whereas we were interested in a percentage in mass (and ultimately in energy). However, we assumed that both percentages were equivalent since there were no clear preferences for any size class (see 'Results') within the range of fish lengths discarded (most fish not exceeding 15 to $20 \mathrm{~cm}$ in length; Arcos 2001). In order to convert mass into energy, we incorporated the average $C A L$, which was estimated as follows

$$
C A L=\sum_{i=1}^{7} M F_{j} \times P I_{i}^{\prime} \times C A L_{i}
$$

where $M F_{i}$ is mass of fish type $i$ in the discards, $P I_{i}^{\prime}$ is the preference of shearwaters for this fish type, and $C A L_{i}$ is the energy content of $i$ (see Table 1). $P I_{i}^{\prime}$ values slightly differ from those presented in Table $1\left(P I_{i}\right.$, which results from the calculation explained above), since the former were weighted to average 1 . The energy content for each group of fish was obtained through lipid extractions of 15 fish species representative of discards, totalling 75 samples (5 samples per species, each sample being the result of pooling and 
Table 2. Puffinus mauretanicus. Input parameters for the model estimating the significance of discards for Balearic shearwaters during the breeding period. $\mathrm{n}=$ sample size; $\mathrm{CV}=$ coefficient of variation, calculated from absolute or transformed data

\begin{tabular}{|c|c|c|c|c|c|}
\hline \multicolumn{2}{|l|}{ Parameter } & Mean & $\mathrm{n}$ & Transformation & $\mathrm{CV}(\%)$ \\
\hline \multicolumn{6}{|l|}{ Energy consumed } \\
\hline \multicolumn{2}{|l|}{ Commercial catches $\left(C C, \mathrm{~kg}\right.$ vessel $\left.^{-1} \mathrm{mo}^{-1}\right)$} & 4486.4 & 20 & Square root & 12.1 \\
\hline \multicolumn{2}{|l|}{ Discard ratio $(D R, \%)$} & 83.5 & 34 & Square root & 34.1 \\
\hline \multicolumn{2}{|l|}{ Consumable fraction of discards $(C F, \%)$} & 69.5 & 27 & Arcsine & 29.8 \\
\hline \multicolumn{2}{|l|}{ Consumption rate $(C R, \%)$} & 1.6 & 20 & Arcsine & 75.6 \\
\hline \multicolumn{2}{|l|}{ Energy content $\left(C A L, \mathrm{~kJ} \mathrm{~g}^{-1}\right)$} & 6.7 & 80 & No & 4.2 \\
\hline \multicolumn{2}{|l|}{ Assimilation efficiency $(A E, \%)$} & 75 & - & - & 0 \\
\hline \multicolumn{6}{|l|}{ Energetic requirements } \\
\hline \multicolumn{2}{|l|}{ Body mass $(B M, g)$} & 496.6 & 448 & No & 9.0 \\
\hline \multirow[t]{2}{*}{ Field metabolic rate $\left(F M R, \mathrm{~kJ} \mathrm{~d}^{-1}\right.$ bird $\left.^{-1}\right)$} & Breeders & 1095.3 & 14 & No & 12.3 \\
\hline & Non-breeders & 702.1 & & & \\
\hline \multirow[t]{2}{*}{ Number of shearwaters $\left(N_{\mathrm{S}}\right)$} & Breeders & 6600 & - & - & 0 \\
\hline & Immatures & 3863 & - & - & 0 \\
\hline
\end{tabular}

homogenising between 2 and 10 fish of similar size; Arcos 2001). These extractions were conducted using a Soxhlet apparatus (see general procedure in Reynolds \& Kunz 2001), to separate lipids from the rest of the substances (the so-called lean fraction). This latter fraction was assumed to be formed by proteins (cf. Ricklefs 1974). Thus, using energetic equivalents for lipids and proteins (e.g. from Ricklefs 1974), we obtained an energetic value for each fish species. We assumed an assimilation efficiency of $75 \%$ following Furness (1990) and measured without error (Stratoudakis 1999).

The energetic requirements of the Balearic shearwater population were estimated from multiplying $F M R$ by the number of shearwaters $\left(N_{\mathrm{S}}\right)$, considering a period of 3 mo (March to June). FMR was considered as 3.9 times the basal metabolic rate $(B M R)$ for breeders and 2.5 times $B M R$ for non-breeders, following Garthe et al. (1996). In turn, $B M R\left(\mathrm{~kJ} \mathrm{~d}^{-1}\right)$ was estimated as $2.30(B M)^{0.774}$ according to Bryant \& Furness (1995), where $B M$ was obtained from individuals caught at colonies $(B M=496.6 \pm 44.6 \mathrm{~g} \mathrm{SD}, \mathrm{n}=448$; unpubl. data). Although these equations were estimated for North Atlantic seabirds and could give slightly high values for a temperate seabird such as the Balearic shearwater, no estimations are available from the study area. Variability of metabolic estimates was obtained from Furness \& Bryant (1996). The total breeding population of Balearic Shearwaters was considered to be 3300 pairs (Aguilar 1991). We also estimated a number of immatures (sum of 1-, 2-, and 3-yr old individuals) considering a breeding success of 0.65 chicks per pair (unpubl. data), a first year survival of 0.70 and a second and third year survival of 0.80 , and considering the sum of individuals surviving from the 3 previous cohorts. Since we have no data about the proportion of non- breeding adult (i.e. physiologically mature) birds, we did not take this parameter into account.

Statistical analysis. Data were first tested for normality, using Shapiro-Wilk's test. When data were not distributed normally, we either made the appropriate transformations (input data in the model) or used nonparametric statistics, following Zar (1996). Comparisons of the number of birds associated with fishing vessels according to their activity were performed grouping censuses for each haul (matched-data), by means of the Friedman 2-way analysis of variance (ANOVA), given the interdependence of the data. Post-hoc comparisons were then performed with the Wilcoxon matched-pairs test. In the other cases, MannWhitney $U$ - and the Kruskal-Wallis tests were employed. $\chi^{2}$ goodness of fit test and contingency tables were also used when appropriate, as well as Spearman's rank correlation.

Significance level was held at 0.05, although marginal values are also discussed following Stoehr (1999). All tests were 2-tailed. The problem of pseudoreplication was partially avoided by considering only 1 count haul ${ }^{-1}$ (that of the maximum number of birds). In addition, hauls were usually well separated in time and space. In the case of strip-transect counts, we regrouped those $10 \mathrm{~min}$ counts that were conducted one immediately after the other in longer periods (series or transects), thus reducing interdependence of data (e.g. Hairston 1989).

\section{RESULTS}

\section{Censuses of birds attending fishing vessels}

Balearic shearwaters attended commercial trawlers regularly, especially during their breeding season 

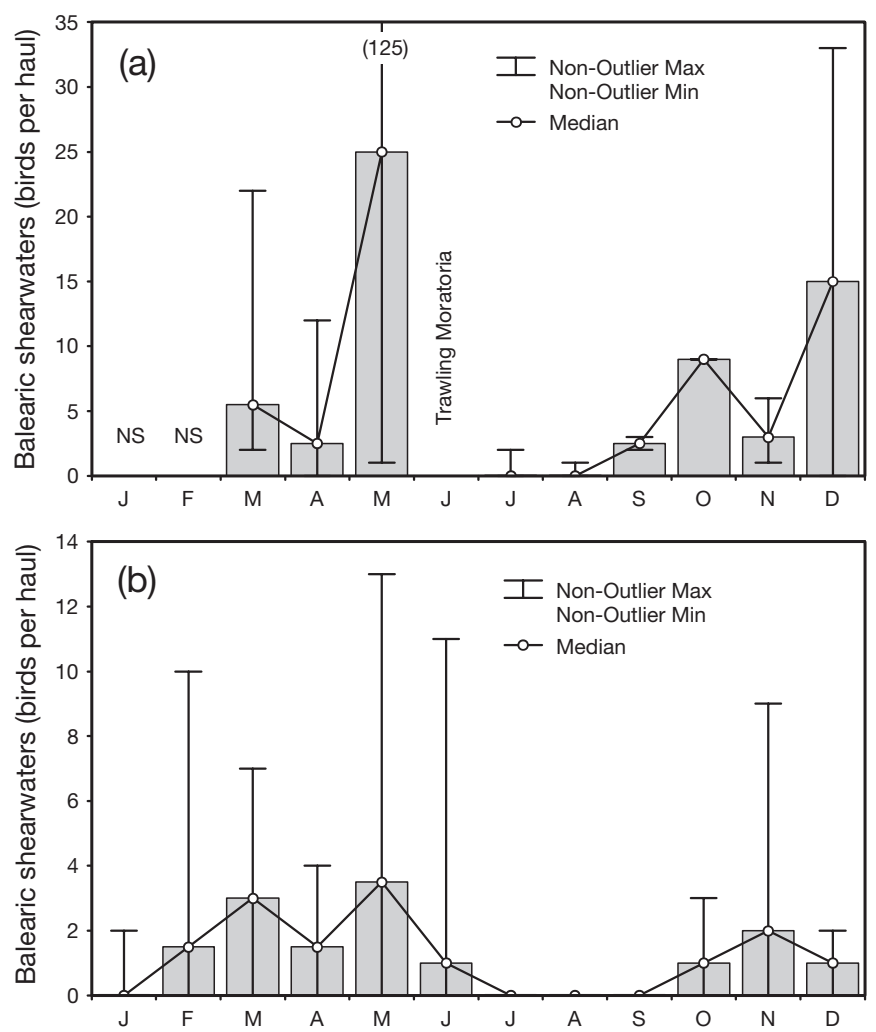

Fig. 3. Puffinus mauretanicus. Monthly numbers of Balearic shearwaters (median and non-outlier range of the maximum counts per haul) associated with trawlers off the Ebro Delta (a) and off Barcelona (b). January and February were not sampled (NS) off the Ebro Delta, while trawling moratoria always included June during the years of fieldwork at this site

(March to June; see Table 3, Fig. 3). The most important concentrations of shearwaters associated with these vessels were observed off the Ebro Delta, with the largest figures occurring in May (Fig. 3). Experi- mental trawling surveys conducted during the late spring confirmed the attendance of Balearic shearwaters to this fishing practice throughout the study area, and showed the largest concentrations in the Ebro Delta-Columbretes area, with lower importance of the Alicante-Ibiza and the central-north Catalonia areas, and very few birds in the Alboran Sea-Vera Gulf area (Kruskal-Wallis test, $H_{3,229}=82.3$, $p<0.0001$; Fig. 4). Post-hoc analysis showed significant differences between all these areas, with the exception of Alicante-Ibiza and central-north Catalonia. Very few shearwaters attended trawlers off their main colonies (Formentera-Ibiza), although some birds were observed there in direct flight, presumably moving towards or from the Iberian shelf.

Purse seiners also attracted Balearic shearwaters, although usually in lower numbers than did trawlers (Table 3). This occurred basically during the discarding process, at dawn (data presented in Table 3); the presence of Balearic shearwaters at night, during the hauling of the net, was rare (mean $=0.2$ birds haul ${ }^{-1}$, $10.5 \%$ of presence, $\mathrm{n}=19$ hauls; Wilcoxon matchedpairs test, $\left.T_{18}=2.0, \mathrm{p}<0.005\right)$. During the breeding season, the number of shearwaters at these vessels tended to be higher coinciding with local trawling moratoria, although the difference was not statistically significant (Mann-Whitney test, $U_{3,7}=3.0, \mathrm{p}=0.09$ ).

Near trawlers, Balearic shearwaters reached their highest numbers in those moments of maximum offer of discards (mean $=6.15$ birds behind the vessel), with lower attendance when the net was being hauled (3.96 birds), and even lower when very few discards were thrown overboard (2.94 birds; Friedman's test, $\left.\chi_{\mathrm{r}}^{2}=44.7, \mathrm{p}<0.0001\right)$. The shearwaters captured sinking discards using either plunge-dives or surface-dives (sensu Ashmole 1971), usually at some distance from the trawler (ca. 50 to $300 \mathrm{~m}$ ). Less often Balearic shear-

Table 3. Puffinus mauretanicus. Numbers of Balearic shearwaters attending commercial fishing vessels (trawlers and purse seiners) off Barcelona and off the Ebro Delta, according to the season (breeding: March-June; post-breeding/moulting: July-October; pre-breeding/wintering: November-February). The median and the mean values of maximum counts per haul/discarding operation are given along with the range (for purse seiners we only considered the discarding process). Percentage of hauls/discarding operations with presence of Balearic shearwaters $(\mathrm{P})$ and percentage among the total seabirds counted behind the vessel (\%n). $\mathrm{n}=$ number of hauls/discarding operations

\begin{tabular}{|c|c|c|c|c|c|c|c|c|c|c|}
\hline \multirow{2}{*}{ Area/period } & \multicolumn{5}{|c|}{ - Trawlers } & \multicolumn{5}{|c|}{ Purse seiners } \\
\hline & $\mathrm{n}$ & $\mathrm{P}(\%)$ & $\% n$ & Median/mean & Range & $\mathrm{n}$ & $\mathrm{P}(\%)$ & $\% n$ & Median/mean & Range \\
\hline \multicolumn{11}{|l|}{ Ebro Delta } \\
\hline Breeding & 23 & 95.7 & 26.4 & $10 / 55.4$ & $0-550$ & 10 & 80.0 & 11.0 & $4 / 6.3$ & $0-21$ \\
\hline Moulting & 24 & 50.0 & 1.1 & $0.5 / 1.7$ & $0-9$ & 7 & 28.6 & 0.4 & $0 / 0.4$ & $0-2$ \\
\hline Wintering & 14 & 92.9 & 2.4 & $4 / 8.4$ & $0-33$ & 2 & 100 & 9.6 & $9.5 / 9.5$ & $9-10$ \\
\hline \multicolumn{11}{|l|}{ Barcelona } \\
\hline Breeding & 77 & 72.7 & 5.5 & $2 / 4.9$ & $0-38$ & & & & & \\
\hline Moulting & 75 & 29.3 & 0.3 & $0 / 0.4$ & $0-4$ & & & & & \\
\hline Wintering & 28 & 60.7 & 1.7 & $1 / 2.8$ & $0-27$ & & & & & \\
\hline
\end{tabular}



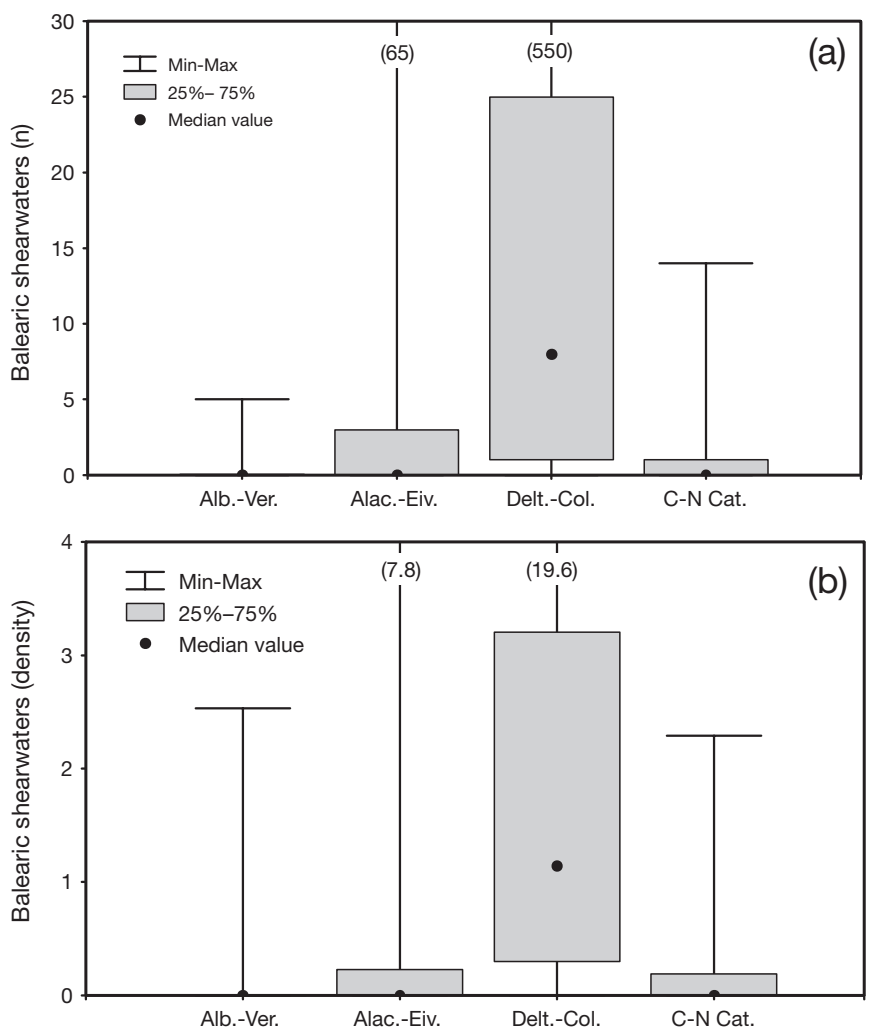

Fig. 4. Puffinus mauretanicus. Numbers of Balearic shearwaters (median and range) recorded during experimental trawling surveys in May-June of 1999 and 2000, according to the geographical area (Alboran-Vera Gulf; Alicante-Ibiza; Ebro Delta-Columbretes; central-north Catalonia). Data presented are the number of birds per haul (a), and the density

(birds $\mathrm{km}^{-2}$ ) recorded during band transect counts (b)

waters approached the vessel and captured discards shortly after these were thrown overboard, a behaviour that mostly occurred when the shearwaters were present in large numbers.

\section{Discard experiments}

The efficiency of Balearic shearwaters at capturing discards was very low according to their success index $(S I$, mean $=-0.85$, ranging from -0.31 to $-1, \mathrm{n}=36$ experiments). Despite that, the shearwaters could capture more discards than observed, since their diving behaviour could allow them to take items assumed to be sunk and lost to seabirds, at considerable distances from the vessel. Moreover, the shearwaters swallowed their prey underwater, making it even more difficult to detect their captures during the experiments. This interpretation is supported by the fact that the success index was highest when high numbers of shearwaters attended the trawler (Spearman's correlation, $r_{s}=0.60$, $p<0.0001)$, since in these cases the birds usually approached the vessel and were more easily detected when capturing fish. Kleptoparasitic events involving Balearic shearwaters (always as hosts) were recorded on 3 occasions $(6.5 \%$ of the attempts to capture discards by the shearwaters, $\mathrm{n}=46$ ). These attacks were performed by yellow-legged gulls Larus cachinnans $(\mathrm{n}=2)$ and Audouin's gulls Larus audouinii $(\mathrm{n}=1)$, and were successful on only 1 occasion.

Balearic shearwaters showed significant differences in the selection of different fish type groups (chisquare goodness of fit test, $\chi^{2}{ }_{6}=15.7, p=0.02, n=2786$ items offered and 40 items swallowed; see PI in Table 1). Clupeoids (anchovy Engraulis encrasicolus and sardine Sardina pilchardus), gadoids, and flatfish were captured more often than expected, while the bogue Boops boops, the gobies and dragonets (Gobiidae and Callionymidae), and the remaining species (grouped as 'others') were captured less often. Regarding fish size, there were no significant differences in the selection of the 3 size-classes considered (contingency table, $\chi_{2}^{2}=0.55, p=0.8$ ). However, discards longer than $20 \mathrm{~cm}$ captured by the shearwaters were in all cases eel-like fish, more easily swallowed, whereas no roundfish or flatfish of this size class was taken.

\section{Strip-transect counts}

A total of 1194 Balearic shearwaters was recorded during transect counts. The mean density was 0.58 birds $\mathrm{km}^{-2}$, with no significant differences between years (Mann-Whitney test, $U_{168,114}=9020.5$, $\mathrm{p}=0.4$ ). Transect counts revealed the same geographical pattern as that obtained from censuses of birds attending experimental trawling, with the highest densities in the Ebro-Delta-Columbretes area, lower representation in the Alicante-Ibiza and the central-north Catalonia areas, and very low densities in the Alboran Sea-Vera Gulf area (Kruskal-Wallis test, $H_{3,282}=102.8$, $p<0.0001$; Figs. $2 \& 4$ ). When considering the sea depth and the distance to the coast, the density of shearwaters was highest in areas less than $100 \mathrm{~m}$ deep (Kruskal-Wallis test, $H_{2,282}=62.3, \mathrm{p}<0.0001$ ), while this parameter increased with the distance to the coast (Kruskal-Wallis test, $H_{2,282}=7.2, \mathrm{p}=0.03$ ). However, neither the effect of the sea depth nor the distance to the coast was significant in any case when considering each of the 4 areas separately, suggesting that these differences were in part the result of different topographic features between areas differing in their average densities of shearwaters.

During transect counts we observed Balearic shearwaters feeding actively on 21 occasions, which involved 245 birds (Fig. 5). The most frequent foraging 


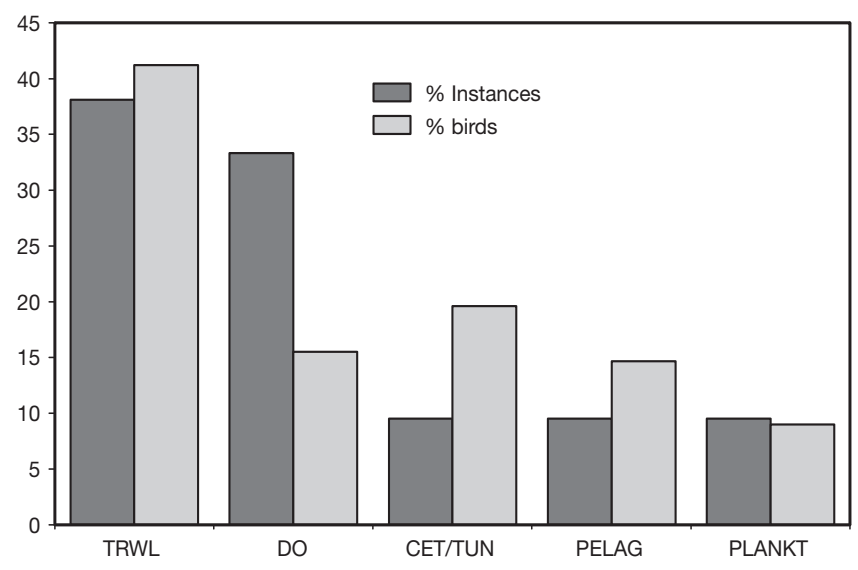

Fig. 5. Puffinus mauretanicus. Feeding strategies by Balearic shearwaters observed during transect counts: percentage of instances $(\mathrm{N}=21)$ and percentage of birds involved $(\mathrm{n}=245)$. The strategies observed were the association with trawlers (TRWL); the capture of fish under floating drifting objects (DO); the association with sub-surface predators (CET/TUN); the direct capture of small pelagic fish (PELAG); and the association with masses of plankton (PLANKT)

strategy was the capture of discards behind trawlers, which was observed on 8 occasions and involved 101 birds. The capture of fish under floating drifting objects was also frequent during daylight hours, although involved fewer birds ( 7 instances, 38 birds). Other foraging strategies were less frequently observed and included the association of shearwaters with sub-surface predators (striped dolphins Stenella coeruleoalba), the direct capture of small pelagic fish close to the sea surface, and the capture of planktonic organisms occurring in high densities. The latter behaviour was only observed at times of low light levels (late evening).

\section{Bioenergetic model for Balearic shearwaters}

According to our model, the Balearic shearwater population meets $40.8 \%$ of its energetic requirements from trawler discards during the breeding season (March to June), though this estimate was subject to strong variability $(\mathrm{CV}=88.7 \%, \mathrm{SD}= \pm 36.2 \%)$. According to this value, an average of 4272 shearwaters could meet their energetic requirements by feeding solely on discards. Considering numbers of breeders and nonbreeders and the different energetic requirements of the 2 groups, and assuming equal efficiency at capturing discards, breeders would obtain in average $35.4 \%$ of their energetic requirement from trawler discards, whereas the estimate for non-breeders would be of $55.3 \%$. In the case that only breeders were present within the area considered in the model, they would obtain $56.2 \%$ of their energy requirements from discards.

\section{DISCUSSION}

\section{Breeding season, extensive use of discards}

This study reveals the importance of discards for Balearic shearwaters, especially during the late breeding season (May to June). At this time of year the productivity of the Mediterranean decreases due to the stratification of water masses, which reduces the availability of nutrients in the photic zone and leads to a general impoverishment of the surface layers (e.g. Margalef 1985, Salat 1996). Trawlers could then be of special importance since they provide demersal prey (unavailable to surface-feeding seabirds except through discards) at a time when the energetic requirements of these seabirds are the highest (i.e. chick rearing) and pelagic prey is less available. In accordance with that, the distribution of the shearwaters at sea in the area surveyed coincided with the main grounds of trawling fisheries in the western Mediterranean, which are especially important off the Ebro Delta (e.g. Lostado 1997). Hydrographic features, however, could also explain this distribution. Despite the general impoverishment of surface waters, several mechanisms leading to fish aggregations may be important at a local scale during the spring-summer, such as shelf-slope fronts and river runoff (Estrada 1996, Salat 1996). This is the case of the area under consideration, which is substantially influenced by the Liguro-Provençal-Catalan front and by the Ebro River runoff. Associated with this relatively high productivity, anchovies spawn in this area mostly during June and July (Palomera 1992), and probably represent another important reason for the shearwaters to forage there. Finally, these foraging grounds could also be influenced (constrained) by the location of colonies (Forbes et al. 2000), though the large potential foraging range of shearwaters (Warham 1996) does not support this idea.

Balearic shearwaters are well adapted to diving, and can reach depths of almost $30 \mathrm{~m}$ (Mayol et al. 2000). This allowed the shearwaters to capture sinking discards at considerable distances from trawlers. This behaviour differed considerably from that of gulls and terns attending these vessels (Oro \& Ruiz 1997, Arcos 2001), thus reducing direct competition (e.g. Furness et al. 1992, Garthe \& Hüppop 1998b, Arcos et al. 2001), although the shearwaters were occasionally subject to kleptoparasitic chases. Purse seiners seemed less attractive to the shearwaters since they attracted fewer birds, and did so almost exclusively during the dis- 
carding activity in daylight (cf. Arcos \& Oro 2002). The shearwaters showed a special preference for Clupeoids among trawler discards, and only obtained this kind of prey from purse seiners. This should be taken into account when assessing the importance of discards through dietary studies, as Clupeoids are also the typical prey captured by shearwaters when feeding on their own (Snow \& Perrins 1998).

According to the bioenergetic model, trawler discards supply about $41 \%$ of the energy requirements of the Balearic shearwater population during the breeding season, though this estimate is subject to strong variability and should be considered with caution. For several reasons, it seems likely that the actual significance of discards for Balearic shearwaters is even higher. Firstly, the rate of capture of discards behind trawlers could have been underestimated since the diving behaviour of Balearic shearwaters behind fishing vessels makes it difficult to detect their captures. Moreover, fish in discard experiments are offered in small amounts, thus being easily captured by gulls and terns that keep close to the vessel. When fishermen discard fish in large amounts the proportion of fish captured by gulls and terns probably decreases since the discards often sink quickly, thus increasing the availability of fish for the shearwaters (cf. Garthe \& Hüppop 1998a). Secondly, we did not consider purse seiners in the model, due to the unpredictability of their discards (Arcos \& Oro 2002), but these vessels still provide some food to the shearwaters. Thirdly, we considered that the whole population of Balearic shearwaters forage within the area considered for the model, though the foraging range of the shearwaters would allow some birds to feed in other areas, and immature birds could move to the Atlantic when adults are still breeding (cf. Bourne et al. 1988). Therefore, the estimated amounts of discards captured by shearwaters should be compared with the requirements of only a fraction of the whole population, and would represent a higher proportion of these requirements. At the same time, birds outside the area considered could also feed on discards, as suggested by our observations during experimental trawls. Finally, the breeding population of Balearic shearwaters has probably decreased in the last decade, and the actual figure seems closer to 2000 breeding pairs (Martí \& Ruiz 2001). This effect could be partly counterbalanced by ignoring non-breeding adults in the model. The establishment of trawling moratoria in spring-early summer could also partly counterbalance the factors previously exposed, since they would reduce the availability of discards. However, these moratoria do not affect all ports, nor are they conducted at the same time by all ports, and thus do not absolutely preclude the consumption of discards by the shearwaters at any time.
Moreover, purse seiners partly compensate for the lack of trawler discards, as shearwaters appeared to attend these vessels in higher numbers during trawling moratoria. In any case, this is important to obtain better estimates of some of the parameters employed in our model, such as consumption rate, commercial catches, and relationship between commercial catches and discards. Meanwhile, our present estimate seems appropriate to confirm the importance that discards play on the feeding ecology of Balearic shearwaters, at least during their breeding season.

During transect counts, Balearic shearwaters used several feeding strategies. In hours of high light levels, these strategies were related with processes that drive or keep prey close to the surface, since most pelagic organisms perform diel vertical migrations and are not available close to the surface at these hours (e.g. Giannoulaki et al. 1999). The shearwaters most frequently fed on trawler discards (38\% of the feeding instances observed and $41 \%$ of the birds involved, which approximates and supports our energetic estimate). Floating drifting objects were also often prospected (33\% of the feeding instances observed, although few birds were involved), since they usually attract fish (Arcos et al. 2000). The shearwaters also associated with striped dolphins, which can drive prey towards the sea surface (Oro 1995). On 2 occasions we observed Balearic shearwaters directly preying upon small shoals of pelagic fish. Nocturnal foraging did not seem important (cf. Mayol et al. 2000); only occasionally were Balearic shearwaters observed at night during the cruises on board purse seiners. However, we recorded Balearic shearwaters feeding upon plankton in hours of low light levels, and this could be a common strategy in crepuscular hours, when these prey are closest to the surface (Estrada et al. 1985, Palomera 1991).

\section{Significance of discards outside of the breeding season}

After the breeding season, most of the Balearic shearwater population migrates to the French Atlantic coast (Bourne et al. 1988, Le Mao \& Yésou 1993), where the hydrographic conditions seem more suitable than those in the Mediterranean in summer and early autumn (e.g. Koutsikopoulos \& Le Cann 1996). During this period very few Balearic shearwaters were observed in the study area, but those birds remaining there attended fishing vessels regularly. The shearwaters were common again from late September onwards, although the numbers observed behind trawlers were lower than in the breeding season. Apparently, trawling discards are of little importance 
during the winter, when the shearwaters concentrate in high numbers in coastal and shallow waters off the NE Iberian Peninsula (Gutiérrez \& Figuerola 1995), presumably feeding upon schools of sardine (I. Palomera pers. comm.).

\section{Balearic shearwaters, fisheries, and conservation}

Over the last few decades there has been increasing consciousness of the impact of fisheries on marine ecosystems (Bostford et al. 1997, Tegner \& Dayton 1999, Gislason et al. 2000). This makes necessary the development of new fishing policies based on a precautionary and ecosystem-based approach (FAO 1995). One goal of these policies is to reduce discards, inducing a food shortage that would first affect those seabird species more sensitive to competition (e.g. Furness 1992, Arcos et al. 2001, Oro \& Furness 2002). Given the importance of discards for Balearic shearwaters, they would probably be affected by this reduction, particularly if natural prey (pelagic fish) were unable to compensate for the lack of discards due to overexploitation (cf. Oro 1999). However, direct interspecific competition at trawlers would probably not be severe for the shearwaters, given their particular behaviour at capturing discards. Temporal moratoria are also promoted by the new fishing policies, and are currently applied in our study area. Although moratoria could be unfavourable to Balearic shearwaters in the short term, the associated recovery of the marine ecosystem should be considered a preferential target, and would probably benefit them in the long term. However, the accurate design of trawling moratoria could help to reduce their impact on the shearwaters and other seabirds of conservation concern. So far, local moratoria established in 1991 have been based on preliminary results obtained during the 1960s in the same geographical area (Suau 1979, Lostado et al. 1999), although very little is known about their effects (e.g. Martín 1995). Moratoria outside of the breeding season of the shearwaters, or in the early stages of that season, would probably reduce the effect of these management measures on the feeding ecology of these seabirds.

Acknowledgements. We are extremely grateful to the skippers T., D. and S. Albiol ('Maireta II' and 'Maireta III'), A. Cruelles ('Cruelles-Montserrat'), J. Llambrich ('Na Marinada'), J. Fàbrega ('Germans Fàbrega') and J. P. Llambrich ('Pepito la Lula'), as well as to their crews, for their help and support during the fieldwork at sea. Our gratitude also to all participants on the cruises MEDITS-ES 99 and 00, especially their chief scientist L. Gil de Sola, as well as to the officers and crew of RV 'Cornide de Saavedra'. Many people helped us during the fieldwork, thanks to all of them, with special men- tion to P. Abelló. X. Ruiz, I. Palomera and S. Mañosa kindly assisted us during the preparation of this manuscript, and 4 anonymous referees substantially improved a previous version. Thanks also to M. Roura for her help and support throughout the preparation of this manuscript. This study was partly supported by research projects funded by the European Comission in association with the DARP-Generalitat de Catalunya (LIFE B4-3200/96/502), and the Instituto Español de Oceanografía (MEDITS DGXIV/IEO/054). J.M.A. was supported by a fellowship of the CIRIT-Generalitat De Catalunya (FI/FIAP 98).

\section{LITERATURE CITED}

Abelló P, Oro D (1998) Offshore distribution of seabirds in the northwestern Mediterranean in June 1995. Colon Waterbirds 21:422-426

Abelló P, Arcos JM, Gil de Sola L (in press) Geographical patterns of seabird attendance to a research trawler along the Iberian Mediterranean coast. Sci Mar

Aguilar JS (1991) Resum de l'atlas d'ocells marins de les Balears, 1991. Anuari Ornitològic de les Balears 6:17-28

Araujo J, Muñoz-Cobo J, Purroy FJ (1977) Las rapaces y aves marinas del archipiélago de Cabrera. Naturalia hispánica 12. ICONA, Madrid

Arcos JM (2001) Foraging ecology of seabirds at sea: significance of commercial fisheries in the NW Mediterranean. $\mathrm{PhD}$ thesis, Universitat de Barcelona; http://tdcat.cesca.es/ TDCat-0219102-114337/index.html

Arcos JM, Oro D (2002) Significance of nocturnal purse seine fisheries for seabirds: a case study off the Ebro Delta (NW Mediterranean). Mar Biol 141: (in press)

Arcos JM, Massutí E, Abelló P, Oro D (2000) Fish associated with floating drifting objects as a feeding resource for Balearic shearwaters Puffinus mauretanicus during the breeding season. Ornis Fenn 77:177-182

Arcos JM, Oro D, Sol D (2001) Competition between the yellow-legged gull Larus cachinnans and Audouin's gull Larus audouinii associated with commercial fishing vessels: the influence of season and fishing fleet. Mar Biol 139:807-816

Ashmole NP (1971) Seabird ecology and the marine environment. In: Farner DS, King JS (eds) Avian biology, Vol 1. Academic Press, New York, p 223-287

Botsford LW, Castilla JC, Peterson CH (1997) The management of fisheries and marine ecosystems. Science 277:509-515

Bourne WRP, MacKrill EJ, Paterson AM, Yésou P (1988) The Yelkouan shearwater Puffinus (puffinus?) yelkouan. Br Birds 81:306-319

Brooke M (1990) The Manx shearwater. T \& AD Poyser, London Bryant DM, Furness RW (1995) Basal metabolic rates of North Atlantic seabirds. Ibis 137:219-226

Estrada M (1996) Primary production in the northwestern Mediterranean. Sci Mar 60(Suppl 2):55-64

Estrada M, Vives F, Alcaraz M (1985) Life and productivity of the open ocean. In: Margalef R (ed) Western Mediterranean. Pergamon Press, Oxford, p 148-197

FAO (1995) Code of conduct for responsible fisheries. FAO, Rome

Forbes LS, Martin J, Kaiser GW (2000) Habitat constraints and spatial bias in seabird colony distributions. Ecography 23:575-578

Furness RW (1990) A preliminary assestment of the quantities of Shetland sandeels taken by seabirds, seals, predatory fish and the industrial fishery between 1981-83. Ibis 132: 205-217 
Furness RW (1992) Implications of changes in net mesh size, fishing effort and minimum landing size regulations in the North Sea for seabird populations. JNCC Report 133

Furness RW, Bryant DM (1996) Effect of wind on field metabolic rates of breeding northern fulmars. Ecology 77 : 1181-1188

Furness RW, Ensor K, Hudson AV (1992) The use of fishery waste by gull populations around the British Isles. Ardea 80:105-113

Garthe S, Hüppop O (1998a) Possible biases in experiments evaluating the consumption of discards by seabirds in the North Sea. Mar Biol 131:735-741

Garthe, S, Hüppop O (1998b) Foraging success, kleptoparasitism and feeding techniques in scavenging seabirds: does crime pay? Helgol Meeresunters 52:187-196

Garthe S, Camphuysen CJ, Furness RW (1996) Amounts of discards by commercial fisheries and their significance as food for seabirds in the North Sea. Mar Ecol Prog Ser 136: $1-11$

Giannoulaki M, Machias A, Tsimenides N (1999) Ambient luminance and vertical migration of the sardine Sardina pilchardus. Mar Ecol Prog Ser 178:29-38

Gislason H, Sinclair M, Sainsbury K, O'Boyle R (2000) Symposium overview: incorporating ecosystem objectives within fisheries management. ICES J Mar Sci 57:468-475

Gutiérrez R, Figuerola J (1995) Wintering distribution of the Balearic shearwater (Puffinus yelkouan mauretanicus) off the northeastern coast of Spain. Ardeola 42:161-166

Hairston NG (1989) Ecological experiments: purpose, design and execution. Cambridge University Press, Cambridge

Haney JC (1985) Counting seabirds at sea from ships: comments on interstudy comparisons and methodological standardization. Auk 102:897-898

Heinemann D (1981) A range finder for pelagic bird censusing. J Wildl Manage 45:489-493

Koutsikopoulos C, Le Cann B (1996) Physical processes and hydrological structures related to the Bay of Biscay anchovy. Sci Mar 60(Suppl 2):9-19

Krebs CJ (1989) Ecological methodology. Harper Collin Publishers, New York

Le Mao P, Yésou P (1993) The annual cycle of Balearic shearwaters and western Mediterranean yellow-legged gulls: some ecological considerations. In: Aguilar JS, Monbailliu X, Paterson AM (eds) Status and conservation of seabirds. Proc 2nd Mediterranean Seabird Symposium, SEO/BirdLife, Madrid, p 135-145

Lostado R (1997) Recursos y pesquerías en el Mediterráneo español. Papeles de Economía Española 71:133-145

Lostado R, Vivas D, del Río V (1999) El Plan Experimental de Pesca de Arrastre de Castellón (1961-66): Enseñanzas de una estrategia de ordenación pesquera sostenible. Informes y Estudios COPEMED. AECI \& FAO (in Spanish). Engl version at: www.ua.es/copemed/reports/plancast

Lowe PR (1921) Description of Puffinus puffinus mauretanicus. Bull Br Ornithol Club 41:140-141

Margalef R (1985) Introduction to the Mediterranean. In: Margalef R (ed) Western Mediterranean. Pergamon Press, Oxford, p 1-16

Martí R, Ruiz A (2001) La pardela balear, ave del año 2001. La Garcilla 110:15-17

Martín P (1995) Effect of a two months closed season on monthly catches of hake (Merluccius merluccius) and red mullet (Mullus spp.) in a restricted area off the Catalan

Editorial responsibility: Otto Kinne (Editor), Oldendorf/Luhe, Germany
Coast (NW Mediterranean). Rapp Comm Int Mer Médit $34: 249$

Mayol J, Aguilar JS, Yésou P (2000) The Balearic shearwater Puffinus mauretanicus: status and threats. In: Yésou $\mathrm{P}$, Sultana J (eds) Monitoring and conservation of birds, mammals and sea turtles of the Mediterranean and Black Seas. Proc 5th Medmaravis Symp. Environment Protection Department, Malta, p 24-37

Oro D (1995) Audouin's gulls Larus audouinii associate with sub-surface predators in the Mediterranean Sea. J Ornithol 136:465-467

Oro D (1999) Trawler discards: a threat or a resource for opportunistic seabirds? In: Adams NJ, Slotow RH (eds) Proc 22nd Int Ornithol Congress. BirdLife South Africa, Johannesburg, p 717-730

Oro D, Furness RW (2002) Influences of food and predation on survival and population dynamics of kittiwakes. Ecology (in press)

Oro D, Ruiz X (1997) Exploitation of trawler discards by breeding seabirds in the north-western Mediterranean: differences between the Ebro Delta and the Balearic Islands areas. ICES J Mar Sci 54:695-707

Palomera I (1991) Vertical distribution of eggs and larvae of Engraulis encrasicolus, in stratified waters of the western Mediterranean. Mar Biol 111:37-44

Palomera I (1992) Spawning of anchovy Engraulis encrasicolus, in the north-western Mediterranean relative to hydrographic features. Mar Ecol Prog Ser 79:215-223

Rebassa M, Suàrez M, Sunyer JR (1998) Nota sobre el comportament alimentari de la baldritja balear Puffinus mauretanicus. Anuari Ornitològic de les Balears 12:125-127

Reynolds DS, Kunz TH (2001) Standard methods for destructive body composition analysis. In Speakman JR (ed) Body composition analysis of animals: a handbook of nondestructive methods. Cambridge University Press, Cambridge, p 39-55

Ricklefs RE (1974) Energetics of reproduction in birds. In: Paynter RA (ed) Avian energetics. Nuttal Ornithological Club, Cambridge, MA, p 152-297

Salat J (1996) Review of hydrographic environmental factors that may influence anchovy habitats in northwestern Mediterranean. Sci Mar 60(Suppl 2):21-32

Snow DW, Perrins CM (1998) Birds of the western Palearctic. Concise Edition, Vol 1. Non-Passerines. Oxford University Press, Oxford

Stoehr AM (1999) Are significance thresholds appropriate for the study of animal behaviour? Anim Behav 57:F22-F25

Stratoudakis Y (1999) Recommendations for improving the estimation of the number of seabirds potentially sustained by fisheries discards. Mar Ecol Prog Ser 176:307-309

Suau P (1979) Un ejemplo de regulación de pesquerías. Invest Pesq 43:21-29

Tasker M, Jones PH, Dixon T, Blake BF (1984) Counting seabirds at sea from ships: a review of methods employed and a suggestion for a standarized approach. Auk 101:567-577

Tegner MJ, Dayton PK (1999) Ecosystem effects of fishing. Trends Ecol Evol 14:261-262

Warham J (1996) The behaviour, population biology and physiology of the petrels. Academic Press, London

Zar JH (1996) Biostatistical analysis. Prentice-Hall, New York

Zotier R, Bretagnolle V, Thibault JC (1999) Biogeography of the marine birds of a confined sea, the Mediterranean. J Biogeogr 26:297-313

Submitted: September 5, 2001; Accepted: April 23, 2002

Proofs received from author(s): July 25, 2002 